\title{
FOSSILIZATION AND ACQUISITION: A STUDY OF LEARNER LANGUAGE
}

\author{
Leyla Hasbún Hasbún
}

\begin{abstract}
RESUMEN
Este artículo estudia los errores gramaticales más frecuentes de 159 estudiantes universitarios de inglés como lengua extranjera. Los datos se tomaron de 8 grupos de composiciones que fueron escritas en clase o de tarea, como parte de las actividades del curso. Estas fueron evaluadas y los errores se clasificaron de acuerdo con una taxonomía y se calculó su frecuencia. Los resultados muestran que a pesar de que la frecuencia de ciertos errores aumenta y disminuye en forma aparentemente impredecible, los errores relacionados con la omisión del sujeto, la concordancia entre sujeto y verbo y las formas negativas son más co munes en los principiantes. Además, se observó que los errores en el uso de los artículos, las preposiciones y las formas verbales fueron los más frecuentes en todos los niveles.

Palabras clave: análisis de errores, fosilización, adquisición de una lengua, artículos, preposiciones.
\end{abstract}

\begin{abstract}
This cross-sectional study examined the most frequent grammar errors made by 159 EFL college students. The data consisted of eight sets of writing samples produced either in class or out of class as part of the regular course activities. They were evaluated, and the errors were classified according to an error taxonomy. Results indicate that although the frequency of certain errors increases and decreases unpredictably across levels, errors pertaining to subject omission, subject verb agreement and negative forms tend to be more common in beginners. Furthermore, errors related to the use of articles and prepositions and incorrect verb forms were the most frequent categories across levels.

Key words: error analysis, fossilization, language acquisition, articles, prepositions.
\end{abstract}

\section{Introduction}

The primary goal of this cross-sectional study is to determine the main areas of difficulty in the acquisition of English grammar by EFL college students who are native speakers of Spanish. For this purpose, an analysis of students' errors was selected since errors

Leyla Hasbún Hasbún. Profesora de la Escuela de Lenguas Modernas. Programa de Posgrado en la Enseñanza del Inglés. Universidad de Costa Rica. San Pedro, San José, Costa Rica.

Correo electrónico: leyla.hasbun@ucr.ac.cr

Recepción: 10-5- 2008

Aceptación: 2-7- 2008 
provide evidence of the processes involved in interlanguage development. However, it is important to bear in mind that, as Cook (1993: 22) points out, Error Analysis is "a methodology for dealing with data, rather than a theory of acquisition," and therefore, it does not explain the sources of these errors nor does it provide insight into possible remediation.

A cross-sectional analysis of the errors college students make along the eight semesters that a bachelor's degree program takes was deemed to be appropriate. The intention of this analysis is to shed light on the types of errors that occur only in the earlier stages of acquisition, those that take much longer to be corrected, and those that are persistent over time, and thus, tend to become fossilized in spite of pedagogic interventions. Hopefully, these data will enable grammar teachers to determine which language problems must be tackled in the classroom early on. Teachers need to know which grammar items need to be constantly recycled until awareness is raised and the learners are ready for them, which might reduce the risk of fossilization. In addition, an understanding of the results of this study will make teachers' expectations about what students can acquire in one semester more realistic, and it will also guide teachers to provide grammar-teaching options that are more fruitful in terms of pedagogical success.

\section{Review of the Literature}

\subsection{Error Analysis}

In his discussion of interlanguage, Cook (1993: 17) argues that it is over-simplistic to see "L2 learning only as a relationship between the L1 and the L2. A learner at a particular point in time is in fact using a language system that is neither the L1 nor the L2. Describing it in terms of the L1 and the L2 misses the distinctive features of L2 learning: "a third language system is involved -that of the L2 learner- which also needs to be described." He concedes that the identification of errors and the reconstruction of the learners' intended meaning are subjective processes since errors are not objective facts. In fact, they are established by a process of analysis and deduction (1993: 21).

In his influential book Error Analysis and Interlanguage, Corder (1981) discusses the importance of paying close attention to the learners' interlanguage and to the role of interpretation in the study of learners' errors. He says that we identify errors "by comparing what [the learner] actually said with what he ought to have said to express what he intended to express" (1981: 37). The problem is that quite often teachers are simply wrong about their interpretations or are not sure about them. In his opinion, the best alternative is to ask the learners themselves. This he calls an authoritative reconstruction; however, for obvious reasons, this is not always possible. The next best thing is for the teacher to attempt an interpretation of the intended meaning by paying careful attention to the form of the language and the context in which it was used. He calls this a plausible interpretation. He adds that, in such a situation, it is helpful to know both the learners and their L1

There have been many valid criticisms against Error Analysis. In a recent study, Hamid (2007) argues that plausible interpretations are the product of "intuition and experience, not empiricism," (2007: 108) and consequently, "absolutely correct reconstruction of an idiosyncratic utterance is not always attainable because a complete thought or meaning is actually divided into different segments and the teacher may not be able to guess correctly 
all those fragmented meanings" (2007: 114). In order to determine whether a group of native speakers (NS) and non-native English as a foreign language (NNS EFL) teachers were able to guess learner intention by using the context and the form of the language, Hamid compared their plausible interpretations to those of the student-writers. He found that only $36.7 \%$ of the reconstructions had the exact same meaning as the speaker's intended utterance while the rest exhibited different degrees of correspondence.

Linguists have identified other potential shortcomings in Error Analysis. For example, Schachter (1974) first discussed the problem of avoidance. The author points out that language learners sometimes keep away from using certain features of the language that they perceive to be difficult. This avoidance, which in fact may be part of the learners' systematic second language performance, leads to the absence of certain errors in their output. Consequently, teachers or researchers find themselves unable to obtain vital evidence that would show that a particular language item has not been acquired yet. For example, many students avoid using the subjunctive in that-noun clauses. Instead of saying "They advised that she buy a new laptop," they tend to use the alternative structure "They advised her to buy a new laptop." They also choose modal auxiliaries. For instance, instead of writing "It is important that this homeless child receive love and respect," they are likely to write, "That homeless child should receive love and respect." If learners studiously avoid the use of the subjunctive, then researchers are not able to assess whether or not they can use it correctly.

Another problem is the fact that while some errors are easily observable or overt, others are covert. Brown (2000: 220) explains that utterances containing covert errors are "grammatically well-formed at the sentence level but are not interpretable within the context of communication." For example, "I am a secretary" is a perfectly well formed English sentence; however, this same sentence would be erroneous as a reply to the question "How do you do?" What this situation highlights is the fact that the accuracy of an utterance needs to be established by looking at the context. Not doing so would produce misleading information about the learners' interlanguage in much the same way that avoidance, as Schachter (1974) points out, does. In the words of Hamid (2007: 115), "any error analysis which simply focuses on forms or isolated sentences without reference to the wider context may produce questionable findings."

In the study of errors, it is also important to consider the concept of fossilization. In her analysis of over 30 years of research in the field, Han (2004: 23) concludes that there is no single definition of fossilization. However, she explains that most researchers seem to agree that it "involves premature cessation of development in defiance of optimal learning conditions" and that "fossilizable structures are persistent over time, against any environmental influences, including consistent natural exposure to the target language and pedagogic interventions." She believes that fossilization occurs locally, that is, only in parts of the interlanguage system as opposed to globally, that is, to the entire interlanguage system. Moreover, it is an observable process rather than a product.

Han adds that, for adult learners, the major causes of fossilization are maturational constraints and the influence of the learner's native language. However, the degree of lack of success may vary from learner to learner due to the fact that other variables intervene (2004: 125). Since many of the students in the BA in English program at the University of Costa Rica have come into contact with English at an age that is considered to be beyond a critical or sensitive period for language acquisition, it is necessary to take into account the 
possible effects of maturational constraints in order to determine what can realistically be expected from their output. Hyltenstam and Abrahamsson (2003) summarize recent research on maturational constraints in second language acquisition and state that findings indicate that, on average, the ultimate attainment of learners who begin at a very early age is native-like. On the other hand, after a certain age, this ultimate attainment correlates negatively with higher age of onset of language acquisition, that is, the older the students are when they begin the process of second language acquisition, the more difficult it is for them to acquire native-like proficiency. The authors report that while some researchers attribute this difference to the effects of a biological critical period, others offer alternative interpretations such as various types of changes that happen at a certain age, such as those related to identity, motivation, cognition, input and formal training (2003: 567).

If in fact there are serious constraints as to what learners can acquire, it is important to find out whether formal instruction can foster or facilitate acquisition. Han (2004: 126) claims that the significant role of instruction in SLA is undisputed; however, she takes a balanced view of the situation and cites Bley-Vroman (1989: 47- 48) who asserts that "a whole industry is built on the consensus that instruction matters in foreign language learning," but "not all instruction is expected to be equally successful, and some actually impede success." DeKeyser (2003: 332) hypothesizes different degrees of usefulness of explicit teaching for different levels of difficulty as follows.

Table 1. Degrees of Usefulness of Explicit Teaching (DeKeyser 2003)

\begin{tabular}{ll}
\hline Rule Difficulty & Role of Instruction \\
\hline Very easy & Not useful. Not necessary. \\
Easy & Speeds up explicit learning process. \\
Moderate & Stretches the ultimate attainment. \\
Difficult & Enhances later implicit acquisition by increasing chances of noticing. \\
Very difficult & Not useful. Not effective. \\
\hline
\end{tabular}

DeKeyser (2003: 331) explains that "rule difficulty is an individual issue that can be described as the ratio of the rule's inherent linguistic complexity to the student's ability to handle such a rule." Consequently, the degree of difficulty of any given rule varies depending on the individual student's aptitude or experience. In this respect, difficulty is subjective since what is easy for one student might be difficult for another. Furthermore, the objective difficulty of the rule itself-its complexity- may be compounded by other factors such as the novelty or abstractness of semantic categories, semantic redundancy, scope and reliability of the rule, or salience.

\subsection{Studies in Error Gravity}

Hughes and Lascaratou (1982) conducted a study of judgments of error gravity. They used three groups of judges: NNS EFL teachers, NS EFL teachers and educated NS not in the field of EFL. The student errors they selected for the study fell into eight very general categories: vocabulary, prepositions, pronouns, plurals, word order, agreement, verb forms 
other than agreement, and spelling. The researchers found that, except for spelling, the NNS teachers were significantly stricter than their NS counterparts and the NS non-teachers when judging the students' errors. One of the explanations they offered for this mismatch is the fact that native speakers have a more comprehensive knowledge of the language, which enables them to readily accept a wider variety of possible structures. Hasbún (2001: 257) reported similar findings. Using a grammatical and pragmatic judgment task based on a series of messages written by university students, she found that NNS teachers were stricter in both accuracy and appropriateness more frequently than NS teachers.

Another important difference highlighted in Hughes and Lascaratou's research study is that the three groups of judges differed in the criteria they used to establish the seriousness of the errors. While the NNS teachers argued that the most serious errors were those that infringed grammar rules that they considered basic or that were taught early on, the NS non-teachers were more concerned about whether the error in question made the sentence difficult to understand or not. As might be expected, the NS teachers used both criteria but valued intelligibility the most. In addition, Hughes and Lascaratou found that some language samples that were perfectly grammatical such as "Neither of us feels quite happy" were judged ungrammatical by members of the three groups.

\subsection{Studies in Error Frequency}

To investigate the most common errors that a group of ESL students with different L1s made, Dalgish (1991) conducted a research project at a US university He also wanted to determine whether, within a particular error type, there were differences in the kinds of errors produced by speakers of different languages. He employed an error typology that included grammar and lexis. He called them grammatical and semantic categories. Some of the categories he discussed were the article system, subject-verb agreement, vocabulary and idiom, confused part of speech, verb tense, verb forms, word order, prepositions, sentence boundary, and pronouns. Spelling errors were excluded. He found that the most common error type was vocabulary and idiom. Dalgish explains that "vocabulary errors are errors in idiom or word choice that are semantically based, and not easily determinable as grammatically based, like subject-verb agreement, verb tense" (1991: 41). The rest of the error types ranked as follows: agreement, prepositions, articles, and verb forms. He compared his results to those obtained by Stenstrom (1975) who worked with Swedish learners of English but who did not include the category vocabulary in her study. The ranking she obtained was different: verb tense, article, prepositions, agreement and pronouns (1975: 46).

Chodorow, Tetreault and Han (2007) claim that preposition errors account for a substantial proportion of all grammatical errors made by ESL students. They cite a study by Bitchener et al. (2005) who reported that $29 \%$ of all the errors made by 53 intermediate to advanced ESL students were preposition errors. Likewise, they mention a study by Murata and Ishara (2004) who found that $18 \%$ of all the errors detected in the analysis of the written production of a Japanese learner of English were related to preposition misuse.

\subsection{Grammar and Lexis Errors}

In a study of learner errors and the interrelationship between grammar and lexis, Salem (2007: 215) found that most of the mistakes made by a group of advanced learners of English as a foreign language could not be clearly categorized as either grammatical or lexical. To solve this problem, the author proposed modifying this binary distinction. Instead 
of two, she used three categories, which she called lexical, word-dependent, and pure-grammar errors. She grounded her distinction on the concept of word-sensitivity, that is, "the extent of generalizability of a rule that has been infringed" (2007: 213).

The first category, lexical errors, includes incorrect word choice, word form or word collocation. She claims that these errors are word-sensitive to varying degrees. Lexical collocations, for example, are at the strong end of the word sensitivity continuum while word form seems to be closer to the pure-grammar end. The second category refers to situations where a word-intrinsic grammatical requirement is not applied, that is, the problem is caused by a violation of a rule that depends on the lexical items involved. For example, the verb "enjoy" belongs to a limited group of verbs that, when followed by another verb, the latter will be a gerund. This is an inherent characteristic of the verb "enjoy." The final category includes errors produced by the misapplication of a widely applicable grammar or syntax rule. In a grammaticality judgment task, she found that NS and NNS teachers judged errors attributed to the violation of generalizable grammar rules more severely than word-sensitive errors, that is, those caused by disregarding a word-intrinsic requirement.

Salem claims that the understanding of these differences might contribute to the development of linguistic awareness. Based on this type of error analysis, teachers might want to provide different kinds of feedback, depending on the specific error. When faced with a case of a highly word-sensitive error, the teacher might simply tell the learners that this is how the word is used. However, if there is space for a grammatical generalization, then the teacher might respond in a different way and lead the learners to discover that generalization by themselves.

To summarize, Dalgish's, and especially Salem's study, show the importance of being aware of the fact that, quite frequently, it is difficult to categorize an error as either purely grammatical or purely lexical. Therefore, when deciding on an error taxonomy, researchers need to describe the general categories as fully as possible to avoid confusion.

Barcroft (2007: 317) believes that a great deal of syntactic information is contained at the word level, a premise that is consistent with the connectionist view of language learning as espoused by Rumelhart and McClelland (1986). In other words, the ability to use grammatical items correctly and fluently depends on repeated associations between individual words or word combinations that take place in multiple contexts. Obviously, to build close associations takes a long time because they are based on repeated input processing as well as on associative learning.

\subsection{Research Questions}

The primary goal of this cross-sectional study is to determine the main areas of difficulty in the acquisition of English grammar by EFL college students who are native speakers of Spanish and answer the following research questions:

- What types of grammar errors tend to occur only in the earlier stages of acquisition?

- What types of grammar errors tend to take much longer to be corrected?

- What types of grammar errors are persistent over time, and thus, tend to become fossilized in spite of pedagogic interventions? 


\section{Methodology}

\subsection{Participants}

The present study was conducted in the School of Modern Languages at the University of Costa Rica. Eight groups of students ranging from beginners to advanced learners of English were randomly selected. They were enrolled either in the B.A. in English or the B. A. in Teaching English as a Foreign Language. Most were between the ages of 18 and 22. Table 2 briefly describes the courses that the students were taking at the time. These descriptions are based on those provided by the course syllabi. Table 2 also gives the number of students that were present on the days when the data were collected.

Table 2. General Information about the courses where the data were collected

\begin{tabular}{|c|c|c|}
\hline Course & Description of the Course & $\begin{array}{c}\text { Number of } \\
\text { students }\end{array}$ \\
\hline $\begin{array}{l}\text { LM-1001 } \\
\text { English I }\end{array}$ & $\begin{array}{l}\text { This is an introductory English course where the four basic skills are } \\
\text { taught in an integrated fashion. Similar amounts of time are devoted to } \\
\text { listening, speaking, reading and writing. No specific prior knowledge } \\
\text { is required although students have supposedly taken at least five years } \\
\text { of English in high school. }\end{array}$ & 18 \\
\hline $\begin{array}{l}\text { LM-1002 } \\
\text { English II }\end{array}$ & $\begin{array}{l}\text { This course is closely related to the preceding one and is designed for } \\
\text { high beginners. The macro-skills are integrated. The general approach } \\
\text { is eclectic. }\end{array}$ & 26 \\
\hline $\begin{array}{l}\text { LM-1235 } \\
\text { English } \\
\text { Composition I }\end{array}$ & $\begin{array}{l}\text { In this first composition class, the principles of writing are discussed. } \\
\text { Students are expected to write coherent and well-structured paragraphs. } \\
\text { Reading materials are meant to contribute to the students' syntactical } \\
\text { and lexical development. Like in the other composition courses, writing } \\
\text { is taught as a process rather than a product; therefore, students are } \\
\text { encouraged to revise drafts systematically. }\end{array}$ & 22 \\
\hline $\begin{array}{l}\text { LM-1245 } \\
\text { English } \\
\text { Composition II }\end{array}$ & $\begin{array}{l}\text { This course introduces the principles of rhetoric. Initially, students } \\
\text { write single paragraphs; then they progress to three-paragraph essays. } \\
\text { Finally, they move on to five paragraphs. }\end{array}$ & 18 \\
\hline $\begin{array}{l}\text { LM-1352 } \\
\text { Rhetoric I }\end{array}$ & $\begin{array}{l}\text { Students are introduced to different genres. They write academic essays } \\
\text { and résumés. In addition, they practice answering essay questions and } \\
\text { using the MLA style sheet. }\end{array}$ & 13 \\
\hline $\begin{array}{l}\text { LM-1362 } \\
\text { Rhetoric II }\end{array}$ & $\begin{array}{l}\text { This course is devoted to argumentative writing. Students discuss con- } \\
\text { troversial issues orally and practice defending their opinions by provid- } \\
\text { ing clear facts. Then they write formal argumentative essays. They use } \\
\text { the APA style sheet. }\end{array}$ & 22 \\
\hline $\begin{array}{l}\text { LM-1472 } \\
\text { Rhetoric IIII }\end{array}$ & $\begin{array}{l}\text { This course is devoted to the writing of formal essays about topics in } \\
\text { literature in preparation for the literature courses in the program as well } \\
\text { as for graduate courses in the field. }\end{array}$ & 23 \\
\hline $\begin{array}{l}\text { LM-1482 } \\
\text { Rhetoric IV }\end{array}$ & $\begin{array}{l}\text { This course is devoted to the writing of research papers in preparation } \\
\text { for graduate school. During the semester, the students develop skills in } \\
\text { designing and reporting research. }\end{array}$ & 17 \\
\hline & TOTAL & 159 \\
\hline
\end{tabular}




\subsection{The Data}

The data used in this cross-sectional study consisted of eight sets of writing samples produced by EFL students either in class or out of class as part of the regular course activities. These samples were written during, or shortly after, the eighth week of the sixteen-week term. Compositions rather than discrete-item exercises such as fill-in-the-blanks exercises were used because it is an accepted fact that a researcher needs enough context in order to make an accurate analysis of the students' errors. In the absence of context, it is very difficult to recover intended meaning. Unlike sentence-level exercises, compositions provide coherent texts. In addition, the topic of the composition as well as the instructions given by the professor further illuminates the intended meaning. Finally, the context also highlights possible covert errors. Table 3 describes the type of writing tasks.

Table 3. Types of Writing Samples

\begin{tabular}{|c|c|}
\hline Course & Type of Writing Sample \\
\hline LM-1001 & $\begin{array}{l}\text { This was an in-class composition. The students were given } 3 \text { possible written } \\
\text { tasks to choose from. The topics were related to those in the textbook; therefore, } \\
\text { they had been previously practiced. }\end{array}$ \\
\hline LM-1002 & $\begin{array}{l}\text { This was an in-class composition. The students were given } 4 \text { possible written } \\
\text { tasks to choose from. The topics were related to those in the textbook; therefore, } \\
\text { they had been previously practiced. }\end{array}$ \\
\hline LM-1235 & $\begin{array}{l}\text { This was an out-of-class composition. Students had read an article about the } \\
\text { topic. Students were asked to write a short paragraph, and it was the first version } \\
\text { of the paper. }\end{array}$ \\
\hline LM-1245 & $\begin{array}{l}\text { This was an out-of-class composition about topics dealt with in the oral } \\
\text { communication class. It was a long paragraph, and it was the first version of } \\
\text { the paper. }\end{array}$ \\
\hline LM-1352 & $\begin{array}{l}\text { The students read a journal article about teaching. In class, they wrote a reaction } \\
\text { paper. This was the first version of the essay. }\end{array}$ \\
\hline LM-1362 & $\begin{array}{l}\text { This was an argumentative paper about health care issues in Costa Rica. The } \\
\text { students wrote the outline at home but wrote the essay in class. }\end{array}$ \\
\hline LM-1472 & $\begin{array}{l}\text { This was the second draft of a paper in which the learners analyzed a poem } \\
\text { written by William Wordsworth. }\end{array}$ \\
\hline LM-1482 & $\begin{array}{l}\text { In class, students read a newspaper article about a current issue, and they wrote } \\
\text { a reaction paper. }\end{array}$ \\
\hline
\end{tabular}

\subsection{Procedure}

In order to trace the students' progress through the eight semesters of the program, writing samples from learners in each of the semesters were collected. Since first-year students do not take a separate writing course, samples were taken in the two Basic English courses. In addition, because there were at least two sections for each of the courses, one of the sections was selected at random. Finally, to guarantee confidentiality, the compositions were given an identification number. 
The next step was to classify the errors. The focus of the analysis was grammatical; therefore, errors concerning organization (i.e., thesis statement, conclusion or transition, etc.), content (i.e., whether the issue was addressed or whether irrelevant material was included, etc.), and mechanics (i.e., punctuation, capitalization, spelling, etc.) were disregarded. Furthermore, errors that were clearly the product of poor or incorrect word choice or word collocation were saved for future research. Table 4 shows the taxonomy of grammar errors employed in the present study. Examples are provided to illustrate each category. Errors under the category "unclear meaning" are those sentences or phrases for which the researcher could not find a plausible interpretation in spite of the fact that she is a native speaker of the students' L1, was familiar with the topic dealt with in the assignment, and had a set of instructions for the assignment.

Table 4. Taxonomy of grammar errors

\begin{tabular}{|c|c|c|}
\hline $\begin{array}{l}\text { General } \\
\text { Category }\end{array}$ & Sub-categories & Examples of Errors \\
\hline \multirow[t]{6}{*}{ Nouns } & number or irregular plural & several kind / a key data \\
\hline & mass / countable nouns & newer equipments \\
\hline & subject omission & In private universities is faster \\
\hline & double subject & It appears to be inevitable the signing of this treaty \\
\hline & possessive noun & indicate that Costa Rican's lack freedom of speech \\
\hline & Noun + Noun & juice of orange \\
\hline Pronouns & wrong antecedent, reference & $\begin{array}{l}\text { person ... they ; body modifications help to express } \\
\text { who they are; theirs objective is }\end{array}$ \\
\hline Articles & missing, unnecessary, wrong & $\begin{array}{l}\text { my life as } \varnothing \text { adult; the fountain of the youth; an } \\
\text { special place }\end{array}$ \\
\hline Demonstratives & & that things \\
\hline Quantifiers & & another persons \\
\hline Possessives & & people ... in your food \\
\hline \multirow[t]{6}{*}{ Verbs } & subject verb agreement & most people is more than bored \\
\hline & wrong verb form & have forgotten of bringing \\
\hline & wrong verb tense & I was working there for a year \\
\hline & modal auxiliary & I will like to thank you \\
\hline & verb missing & they see their lives still the same (are) \\
\hline & direct object missing & Young people like to spend their free time purchasing. \\
\hline \multirow{3}{*}{$\begin{array}{l}\text { Adjectives and } \\
\text { adverbs }\end{array}$} & wrong part of speech & a good paid job \\
\hline & plural adjectives & call their teachers obsoletes \\
\hline & comparative and superlative forms & the mortality rate would be smallest \\
\hline \multirow[t]{3}{*}{ Prepositions } & missing preposition & to operate the patients \\
\hline & wrong preposition & when they arrived to the place \\
\hline & unnecessary preposition & they must attend to seminars to change \\
\hline
\end{tabular}




\begin{tabular}{|c|c|c|}
\hline $\begin{array}{l}\text { General } \\
\text { Category }\end{array}$ & Sub-categories & Examples of Errors \\
\hline Subordination & & $\begin{array}{l}\text { and find someone is required a worker (someone } \\
\text { who requires a worker) }\end{array}$ \\
\hline Expletive & & There is a wonderful place (it is) \\
\hline \multirow[t]{3}{*}{ Word order } & general word order & $\begin{array}{l}\text { More healthy is to do exercise. } \\
\text {...an idea of how beautiful is nature }\end{array}$ \\
\hline & order of adjectives & contact color lenses \\
\hline & order of adverbs & People could do there a lot of activities \\
\hline Negative forms & & $\begin{array}{l}\text { Do diets no is bad. } \\
\text { Your body haven't the same requirements. }\end{array}$ \\
\hline $\begin{array}{l}\text { Unclear } \\
\text { meaning }\end{array}$ & & $\begin{array}{l}\text { In conclusion, this problems don't make that a very } \\
\text { good lifestyle in my neighborhood change. }\end{array}$ \\
\hline $\begin{array}{l}\text { Conditional } \\
\text { forms }\end{array}$ & & $\begin{array}{l}\text { If all people had money to afford an organ transplant, } \\
\text { they will also find space and organs. }\end{array}$ \\
\hline
\end{tabular}

After the analysis, the grammar errors were systematically recorded with sufficient context, that is, sentence length or slightly longer when needed. The student's identification number was also recorded. For each of the groups of students, a master list was compiled.

\section{Results}

Table 5 presents all the grammar errors marked in the students' compositions. The first column lists the error categories, and the rest of the columns, two for each group, show the actual number of errors under each category (raw scores) and the percentage of the total number of errors per group that each raw score represents. 


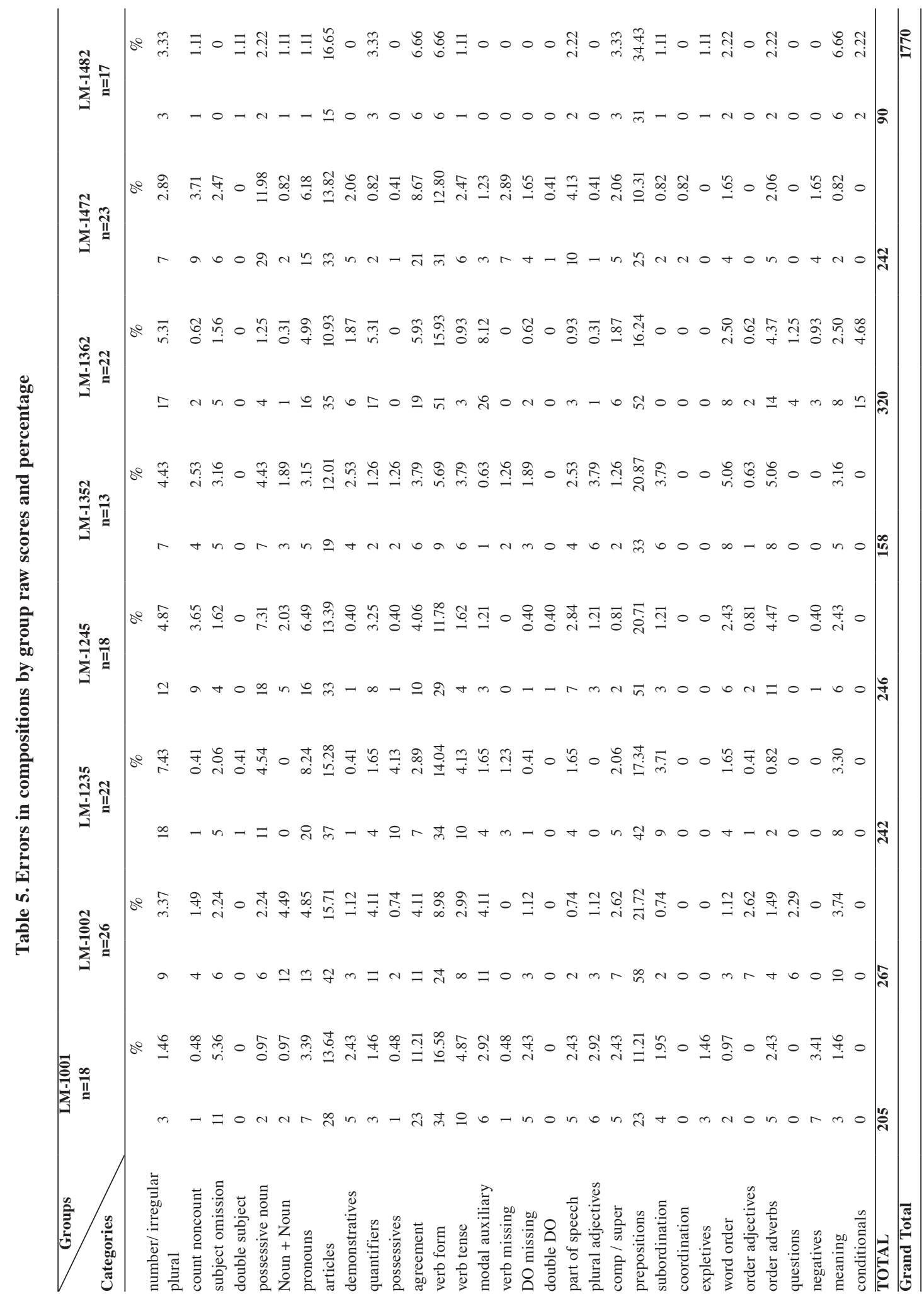


Table 5 shows no neat patterns of behavior that might suggest that some types of errors are exclusive to certain stages of acquisition. In fact, a preliminary examination of the data reveals that the frequency of certain errors increases and decreases unpredictably across levels, which seems to indicate that variables other than level might be responsible for these changes. Two examples are errors concerning the use of noncountable nouns and the misuse of quantifiers as Figure 1 shows.

Figure 1. Noncountable nouns and quantifiers

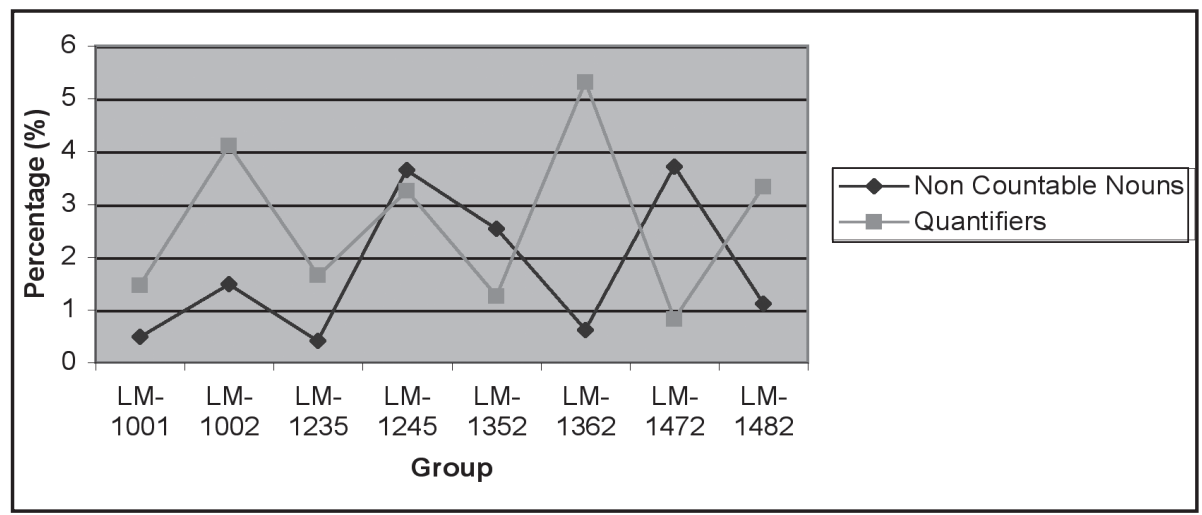

Although Table 5 does not provide a definite answer to the first two research questions, that is, it is not possible to identify a group of errors that is characteristic of the first stages of acquisition, a closer examination of the data shows trends or interesting behaviors. First of all, errors pertaining to subject omission, subject verb agreement and negative forms tend to be more common in the compositions of first semester students than in the writing samples of the rest of the population. Figure 2 helps to visualize the pattern.

Figure 2. Subject omission, agreement and negative forms

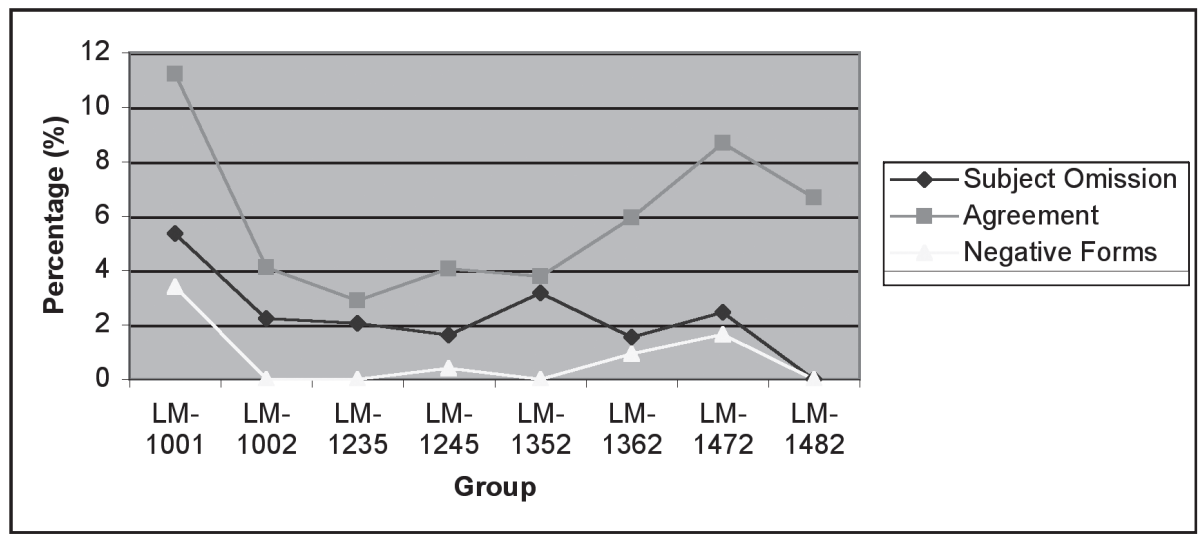


Figure 2 shows that although these mistakes, especially subject verb agreement problems which peak during the seventh semester, are still present in later stages, they seem to be more troublesome for beginners.

Second, Table 5 also shows that the data for first semester students include only 9 categories of errors with a raw score of 1 or 0 while the data for last semester students include the highest number, that is, 19 categories where 0 or only 1 error was recorded. In other words, beginners seem to have trouble with more types of grammar items than the most advanced students do. In all likelihood, this is another sign of development.

Third, the highest number of possessive noun problems is found in LM-1472, a fourthyear course. There is no obvious explanation for this situation, but a plausible one is that the nature of the assignment might have called for an unusually high number of instances where the structure was required, making the problem especially evident. In other words, the students in general might not feel confident about the use of possessive nouns and, therefore, avoid using this grammar form, but when they are forced to use it, then they make numerous mistakes.

Fourth, other remarkable changes in frequency can only be explained when the behavior of individual students is analyzed. For instance, on occasion a single student is responsible for most instances of a "stigmatized" error. A case in point is student number 3 in LM-1352, who made three of the five mistakes concerning subject omission and three of the six errors where adjectives were given plural forms, quite possibly two of the grammar mistakes ESL teachers would rank among the most serious. In fact, this same student is responsible for 24 of the 158 errors recorded for a group of 13 students, in other words, for $15.18 \%$ of the total number of errors. Had the errors been evenly distributed among all the students, this person would have made only 12.1 errors, not 24 . Conceivably, this student has passed the previous courses without being really prepared, a situation that is possible given some of the university evaluation norms.

Another way of looking at the data is to focus only on those errors that are the most frequent. This type of analysis addresses the last research question. Table 6 presents the five most numerous error types by level.

Table 6. Most frequent errors by group: Raw scores and percentages

\begin{tabular}{cccccccc}
\hline $\begin{array}{c}\text { LM-1001 } \\
\mathbf{n = 1 8}\end{array}$ & $\begin{array}{c}\text { LM-1002 } \\
\mathbf{n = 2 6}\end{array}$ & $\begin{array}{c}\text { LM-1235 } \\
\mathbf{n = 2 2}\end{array}$ & $\begin{array}{c}\text { LM-1245 } \\
\mathbf{n = 1 8}\end{array}$ & $\begin{array}{c}\text { LM-1352 } \\
\mathbf{n = 1 3}\end{array}$ & $\begin{array}{c}\text { LM-1362 } \\
\mathbf{n = 2 2}\end{array}$ & $\begin{array}{c}\text { LM-1472 } \\
\mathbf{n = 2 3}\end{array}$ & $\begin{array}{c}\text { LM-1482 } \\
\mathbf{n = 1 7}\end{array}$ \\
\hline verb form & preposition & preposition & preposition & preposition & preposition & articles & preposition \\
34 & 58 & 42 & 51 & 33 & 52 & 33 & 31 \\
$16.58 \%$ & $21.72 \%$ & $17.34 \%$ & $20.71 \%$ & $20.87 \%$ & $16.24 \%$ & $13.82 \%$ & $34.43 \%$ \\
articles & articles & articles & articles & articles & verb form & verb form & article \\
28 & 42 & 37 & 33 & 19 & 51 & 31 & 15 \\
$13.64 \%$ & $15.71 \%$ & $15.28 \%$ & $13.39 \%$ & $12.01 \%$ & $15.93 \%$ & $12.80 \%$ & $16.65 \%$ \\
preposition & verb form & verb form & verb form & verb form & article & possessive & verb form \\
23 & 24 & 34 & 29 & 9 & 35 & noun & 6 \\
$11.21 \%$ & $8.98 \%$ & $14.04 \%$ & $11.78 \%$ & $5.69 \%$ & $10.93 \%$ & 29 & $6.66 \%$
\end{tabular}




\begin{tabular}{|c|c|c|c|c|c|c|c|}
\hline $\begin{array}{c}\text { LM-1001 } \\
n=18\end{array}$ & $\begin{array}{c}\text { LM-1002 } \\
n=26\end{array}$ & $\begin{array}{c}\text { LM-1235 } \\
n=22\end{array}$ & $\begin{array}{c}\text { LM-1245 } \\
n=18\end{array}$ & $\begin{array}{c}\text { LM-1352 } \\
n=13\end{array}$ & $\begin{array}{c}\text { LM-1362 } \\
n=22\end{array}$ & $\begin{array}{c}\text { LM-1472 } \\
n=23\end{array}$ & $\begin{array}{c}\text { LM-1482 } \\
n=17\end{array}$ \\
\hline agreement & $\mathrm{N}+\mathrm{N}$ & pronouns & possessive & word order & modal & preposition & agreement \\
\hline 23 & 12 & 20 & noun & 8 & auxiliaries & 25 & 6 \\
\hline $11.21 \%$ & $4.49 \%$ & $8.24 \%$ & $\begin{array}{c}18 \\
7.31 \%\end{array}$ & $5.06 \%$ & $\begin{array}{c}26 \\
8.12 \%\end{array}$ & $10.31 \%$ & $6.66 \%$ \\
\hline $\begin{array}{c}\text { subject } \\
\text { omission } \\
11\end{array}$ & $\begin{array}{c}\text { agreement, } \\
\text { quantifiers, } \\
\text { modals }\end{array}$ & $\begin{array}{c}\text { number } \\
18 \\
7.43 \%\end{array}$ & $\begin{array}{c}\text { pronoun } \\
16 \\
6.49 \%\end{array}$ & $\begin{array}{c}\text { order of } \\
\text { adverbs } \\
8\end{array}$ & $\begin{array}{c}\text { agreement } \\
19 \\
5.93 \%\end{array}$ & $\begin{array}{c}\text { agreement } \\
21 \\
8.67 \%\end{array}$ & $\begin{array}{c}\text { meaning } \\
6 \\
6.66 \%\end{array}$ \\
\hline $5.36 \%$ & $\begin{array}{c}11 \\
4.11 \%\end{array}$ & & & $5.06 \%$ & & & \\
\hline
\end{tabular}

Except for the students in LM-1472, the three most frequent categories are prepositions, articles and verb forms. For them, prepositions came in fourth place, right after errors concerning possessive nouns, which, as pointed out earlier, were unexpectedly high. These errors are also common in previous studies. Prepositions, articles and verb forms were among the most recurrent in Dalgish (1991). Furthermore, articles and prepositions were also among the most common in Stenstrom (1975). Figure 3 displays the frequencies.

Figure 3. Articles, verb forms, and prepositions

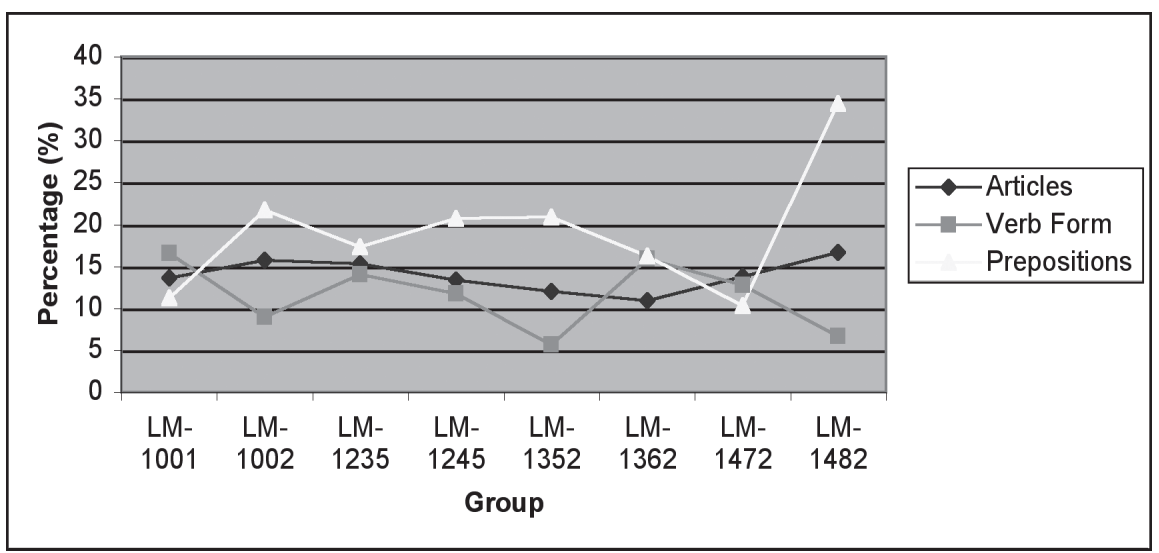

In conclusion, the answer to the last research question is that errors concerning the use of prepositions and articles as well as the utilization of verb forms seem to be persistent over time, and thus, tend to become fossilized in spite of pedagogic interventions. This claim is grounded on the fact that not only are these errors still present in the written work of students in the most advanced composition courses, but they are also the most frequent. This interpretation seems to be supported by the data in Table 7, which shows the five most common error types for all the eight groups. This time the analysis does not focus on the individual groups but on the whole sample. 
Table 7. Most common errors in the entire sample:

Raw scores and percentages

\begin{tabular}{lcc}
\hline \multicolumn{1}{c}{ Category } & Raw Scores & Percentages \\
\hline prepositions & 315 & $17.79 \%$ \\
articles & 242 & $13.67 \%$ \\
verb form & 218 & $12.31 \%$ \\
agreement & 103 & $5.81 \%$ \\
pronouns & 93 & $5.25 \%$ \\
\hline TOTAL & $971 / 1770$ & $54.83 \%$ \\
\hline
\end{tabular}

$\mathrm{n}=159$

total number of errors $=1770$

First of all, it is important to note that errors in these five categories constitute more than half of the total number of errors the students in all levels made. This in itself is quite telling because it provides evidence of possible fossilization in specific language areas.

Another interesting finding is the fact that the highest percentages of errors (not the raw scores) regarding preposition and article use are the ones found for the students in LM1482 , the last writing course in the program. Obviously, this does not mean that the most advanced students make more mistakes in these areas than the beginners. What this actually seems to indicate is the fact that advanced students tend to make fewer types of mistakes than beginners because some of these types have probably been eradicated or have become sporadic. However, mistakes concerning the use of prepositions and articles still persist, and since at this point there are fewer mistakes, they stand out, becoming more noticeable. In most likelihood, neither the acquisition of articles and prepositions nor its teaching has been as successful as the acquisition or teaching of other grammar items.

\section{Conclusions}

If teachers accept DeKeyser's (2003:332) claim that there are different degrees of usefulness of explicit teaching of grammar for the acquisition of rules of various levels of difficulty, perhaps the teaching of articles and prepositions is a case where the rule is difficult or very difficult, and consequently, what instruction can accomplish is only to enhance "later implicit acquisition by increasing chances of noticing" or simply nothing at all because instruction is "not useful." In such a case, teachers would have to provide students with negative evidence, recycle grammar as necessary, and wait until learners are ready for acquisition.

This study and several others have shown that the use of prepositions is one of the main problems in mastering English. Perhaps the reason why this is true is that teachers are not presenting prepositions properly. Lewis (1994: 143) argues that, contrary to popular belief, de-lexicalized words such as prepositions are very powerful pattern generators; therefore, "collecting some of their most important patterns and arranging them in an arresting, non- 
linear format, where words which occur together are recorded together, is more likely to be pedagogically effective." It is absolutely crucial to reconsider the way prepositions have traditionally been taught. Instead of teaching prepositions as isolated words they must be considered integral parts of larger discourse.

On the other hand, although compositions are excellent instruments that allow for accurate meaning reconstruction, and they usually provide a wide range of sentence types, the students are free to choose the language they want to use, which might encourage learners to stay away from those sentence patterns that they do not master yet. Therefore, to better understand the process of language acquisition, students' performance should be further investigated using other tasks such as a grammaticality judgment or a completion task. These tasks would help tease out avoidance problems because the researcher can lead the learners to use target structures that are often absent from compositions.

Finally, when foreign language teachers see little progress, they often agonize over the fact that their students' performance is a sign of the kind and quality of teaching that takes place in their classes. However, they seem to forget that there are other equally important factors that need to be present for successful language acquisition besides teaching methods such as quality input, suitable teaching materials, motivation, linguistic intelligence, aptitude and, of course, time.

\section{Bibliography}

Barcroft, Joe. 2007. "When knowing grammar depends on knowing vocabulary: Nativespeaker grammaticality judgments of sentences with real and unreal words." The Canadian Modern Language Review. 63 (3): 313- 343.

Brown, H. Douglas. 2000. Principles of language learning and teaching. Fourth Edition. New York: Longman.

Chodorow, M. et al. 2007. "Detecting of Grammatical Errors Involving Prepositions." In Proceedings of the Fourth ACL-SIGSEM Workshop on Prepositions. Prague, The Czech Republic.

Cook, Vivian. 1993. Linguistics and second language acquisition. New York: Palgrave Publishers Ltd.

Corder, S. Pit. 1981. Error analysis and interlanguage. Oxford: Oxford University Press.

Dalgish, Gerard M. 1991. "Computer-Assisted Error Analysis and Courseware Design: Applications for ESL in the Swedish Context." CALICO Journal. 9 (2): 39- 56.

Doughty, Catherine and Michael H. Long. 2003. The handbook of second language acquisition . Malden: Blackwell Publishing Ltd. 
DeKeyser, Robert. 2003. Implicit and explicit learning. In Catherine J. Doughty and Michael H. Long (Eds.). The handbook of second language acquisition, 311-348.

Hamid, Obaidul. 2007. "Identifying second language errors: How plausible are plausible reconstructions?" ELT Journal. 61 (2): 107- 116.

Han, ZhaoHong. 2004. Fossilization in adult second language acquisition. Clevedon: Multilingual Matters Ltd.

Hasbún, Leyla. 2001. "Assessment of grammatical errors and pragmatic failure." Revista de Filología y Lingüística. 27 (1): 249- 263.

2007. "Evaluación de un curso de gramática del inglés: Insumo para la investigación." Revista Electrónica Actualidades Investigativas en Educación. 7 (1): 1- 20.

Hughes, Arthur and Chryssoula Lascaratou. 1982. "Competing criteria for error gravity." ELT Journal. 36 (3): 175- 182.

Hyltenstam, Kenneth and Niclas Abrahamsson. 2003. Maturational constraints in SLA. In Catherine J. Doughty and Michael H. Long (Eds.) The handbook of second language acquisition, 539-588.

Lewis, Michael. 1994. The lexical approach: The state of ELT and a way forward. Hove: Language Teaching Publications.

Salem, Ilana. 2007. "The lexico-grammatical continuum viewed through student error." ELT Journal. 61 (3): 211- 219.

Selinker, Larry. 1972. "Interlanguage”. International Review of Applied Linguistics. 10: 209- 31. 